\title{
Eixos: novo paradigma do planejamento regional? Os eixos de infraestrutura nos PPA's nacionais, na lirsa e na macrometrópole paulista*
}

\author{
Axes: a new paradigm of regional planning? \\ Infrastructure axes in the national PPAs, \\ in the lirsa and in the macrometrópole paulista
}

Jeferson Cristiano Tavares

\begin{abstract}
Resumo
0 objetivo deste artigo é problematizar a organização territorial interescalar baseada nos eixos de infraestrutura propostos pelo poder público, entre 1995 e 2015. Sua análise está fundamentada no referencial teórico que demonstra as relações entre (re)estruturação produtiva e organização do território (Logan e Molotch, 1987; Scott, 1998; Brenner, 2010). Foram eleitas, como objetos de estudo, as ações planejadoras propostas pela iniciativa pública, no âmbito federal: os planos plurianuais e seus respectivos programas; no âmbito continental: os planos e propostas da lirsa; e no âmbito estadual: o Plano de Ação da Macrometrópole Paulista (PAM 2013-2040). As conclusões do artigo apontam para um protagonismo em curso do Eixo como elemento estruturador da organização territorial nas suas diferentes escalas orientado pelos preceitos de integração, conectividade e competitividade.
\end{abstract}

Palavras-chave: eixos; planejamento regional; PPA; lirsa; macrometrópole paulista.

\begin{abstract}
Our goal is to discuss inter-scalar territorial organization based on the infrastructure axes proposed by the government between 1995 and 2015. Our analysis is grounded on the theoretical framework that shows the relationship between (re)structuring of production and territorial organization (Logan; Molotch, 1987; Scott, 1980; Brenner, 2010). We chose to study planning actions proposed by public initiative. At the federal level: the PPAs and their programs; at the continental level: the plans and proposals of the lirsa; and at the state level: the Plano de Ação da Macrometrópole Paulista (PAM 2013-2040). Our findings point to the ongoing leading role of the Axis as a structuring element of territorial organization in its different scales, guided by the principles of integration, connectivity and competitiveness.
\end{abstract}

Keywords: axes; regional planning; PPA; lirsa; macrometrópole paulista. 


\section{Introdução}

Nas últimas três décadas, pudemos observar importantes iniciativas de organização territorial baseadas em eixos formados por faixas de infraestrutura (em geral econômica: comunicação, energia e logística) que buscam orientar regionalizações para provisão de recursos públicos e privados. Essas iniciativas têm predomínio após o processo de redemocratização brasileira e ocorrem em escalas diferenciadas (continental, nacional e estadual) e em períodos contínuos, demonstrando o enraizamento de uma ideia. Representam um paradigma de planejamento regional porque avançam em relação ao modelo polarizado preconizado pela escola francesa de planejamento regional, vigente durante a segunda metade do século XX na América do Sul. Além disso, carregam consigo um paradoxo, pois, ao romper com o modelo polarizado, mantêm-se baseadas na matriz econômica a partir da qual a atividade produtiva e a organização territorial exercem influências recíprocas, tal como no modelo francês.

As políticas do pós-Segunda Guerra Mundial que, no Brasil, redundaram no chamado Desenvolvimentismo incorporaram paulatinamente o modelo de Polos de Crescimento (proposto por Perroux em 1955). Esse modelo foi difundido por ações, principalmente, da Cepal (Comissão Econômica para a América Latina e o Caribe, 1948), da CIBPU (Comissão Interestadual da Bacia do Paraná-Uruguai, 1951-1972) e do Plano Decenal 1967-1976 (do governo de Castello Branco) e influenciou planos estaduais (como no estado de São Paulo) e diretrizes institucionais (como no IBGE) (Tavares, 2015). De forma geral, a teoria dos Polos de Perroux apontava para um prognóstico de equilíbrio do desenvolvimento territorial a ser alcançado a partir da indústria motriz e de sua articulação com a cadeia produtiva distribuída controladamente pelo território.

0 que se observa nos modelos de organização territorial propostos recentemente é a incorporação do eixo como elemento estruturador de uma nova regionalização com fins à organização territorial e que, dialogando com os preceitos econômicos vigentes da reestruturação produtiva de origem neoliberal, tenta responder aos problemas de desequilíbrio do desenvolvimento pela integração, conectividade e competitividade regionais. Evidentemente, pela origem e finalidade de cada eixo, eles divergem no seu conteúdo e na sua forma, mas convergem para objetivos e padrões territoriais semelhantes. 0 que se busca neste estudo, portanto, é a caraterização desses eixos, historicizando-os, a fim de compreendê-los numa dimensão maior que o campo político no qual foram concebidos e de inseri-los no contexto socioeconômico com o qual eles se propõem a dialogar.

\section{Os eixos: integração, desenvolvimento e territorialidade nas diferentes escalas}

\section{Eixos Nacionais de Integração e Desenvolvimento nos primeiros PPA's, a partir dos anos 1990}

No âmbito nacional, os Eixos Nacionais de Integração e Desenvolvimento (Enid) foram uma estratégia concebida, de forma preliminar, no 
PPA 1996-1999¹ como matriz para investimentos de infraestrutura em regiões delimitadas a partir de importantes fluxos de escoamento de produtos nacionais. Na sua segunda versão, resultante do Consórcio Brasiliana que objetivou aprofundar a versão do PPA 1996-1999, os eixos constituíram-se em "[...] um instrumento particular [...] para o equacionamento de projetos relevantes com vistas a um planejamento amplo, de abrangência nacional e nítido caráter espacial [...]" (Ablas, 2003, p. 172). Na sua versão novamente revista e conceituada no PPA 2000-2003 (Anexo I - Diretrizes estratégicas e macro-objetivos, tópico Agendas), os eixos foram propostos com a justificativa de equilibrar o desenvolvimento regional e de promover a distribuição de riqueza; além de integrar as regiões por meio de plataformas eficientes que possibilitassem maior competitividade no mercado internacional. Suas diretrizes foram: complementaridade regional por meio de investimentos que proporcionassem o desenvolvimento e a redução das disparidades regionais; desconcentração para criar novos espaços econômicos; participação privada; fortalecimento das relações internacionais com a América Latina e, principalmente com o Mercosul; fortalecimento institucional pelos instrumentos de financiamento; desenvolvimento local integrado a partir da sua influência no âmbito urbano; fomento do setor de serviços; e incentivo e integração das infraestruturas econômicas às redes de infraestrutura social e recursos hídricos (Brasil, 2001, pp. 15-16). Ao longo desse processo (em cerca de 8 anos) os eixos foram considerados o principal instrumento de dinamização territorial e abordaram as infraestruturas econômicas, de informação e conhecimento, de desenvolvimento social e de meio ambiente. $E$, como estratégia de atração de investimentos, tornaram-se uma ação pública a partir da provisão de recursos públicos e privados para irradiar o desenvolvimento: "A realização desses investimentos irradia externalidades favoráveis à atração de empreendimentos produtivos" (Brasil, 2001, p. 15).

A origem dessas versões remete-se ao trabalho de Eliezer Batista (Infraestrutura para o desenvolvimento social e integração na América do Sul, 1997) e à influência desse trabalho sobre o PPA 1996-1999, que tratava dos investimentos em infraestrutura como instrumento de integração espacial.

Para aprofundar as diretrizes do PPA 1996-1999, o governo federal abriu licitação para uma ampla consultoria da qual resultou o trabalho "Identificação de oportunidades de investimentos públicos e/ou privados" desenvolvido pelo Consórcio Brasiliana (formado pelas empresas vencedoras do certame: Booz-Allen \& Hamilton do Brasil Consultores Ltda., Bechtel International Inc. e Banco ABN Amro S.A.) entre os anos de 1998 e 1999 . Os estudos foram acompanhados pelo BNDES (Banco Nacional de Desenvolvimento Econômico e Social) e pelo Ministério do Planejamento, Orçamento e Gestão (Nasser, 2000, p. 166).

A base do discurso dos eixos proposta pelo referido trabalho fundamentou-se na integração física e na preocupação com os "desequilíbrios espaciais e sociais" dessas regiões, independentemente das fronteiras administrativas, aproximando-se do modelo de definição de uma "região de planejamento" (originalmente conceituada por Boudeville no seu Aménagement du territoire et polarisation) (Ablas, 2003, pp. 172-173), sem desprezar as relações polarizadas herdadas da escola francesa. 
Na prática, essa consultoria propôs uma regionalização do território nacional a partir de critérios definidos pelos principais eixos de infraestrutura do País e sua área de influência, considerando a importância de vias de transporte, a funcionalidade das cidades abrangidas, a existência de focos dinâmicos e os aspectos ambientais. 0 objetivo central foi estabelecer uma base física capaz de direcionar os investimentos públicos e privados atrelados a projetos específicos e afins a esses investimentos. Assim, foram definidos nove eixos que resultaram em nove delimitações de regiões: Sul; Sudoeste; Rede Sudeste; São Francisco; Araguaia-Tocantins; Oeste; Transnordestino; Madeira-Amazonas; e Arco Norte.

A partir dessas regiões, foram identificados potenciais, demandas futuras (de transporte, energia e telecomunicações) de oportunidades de investimentos, além de necessidades de serviços sociais que compuseram um "portfólio de investimentos" (Ablas, 2003, pp. 177-178)

Delimitação geográfica dos Enid's referente ao PPA 1996-1999

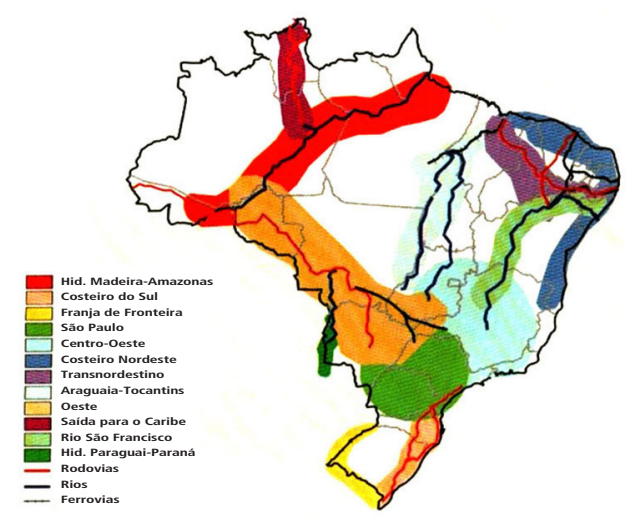

Elaboração: Consórcio Brasiliana (2000).

Fonte: Galvão e Brandão (2003, p. 222). segundo o qual, após revisão e complementação dos estados, estimava-se US\$207 milhões de investimentos necessários.

Por fim, essas nove regiões foram reagrupadas em quatro regiões definitivas:

1) Rede Sudeste, Eixos Sudoeste e Eixo Sul: a mais produtiva do País com predominância de terciário avançado e prioridade para a difusão e competividade;

2) Eixo Oeste e Eixo Araguaia-Tocantins: celeiro de produtos agrícolas para exportação (agropecuária e agroindústria) com prioridade para a logística de alta capacidade;

3) Eixo São Francisco e o Eixo Transnordestino: a mais deficitária e pobre, com prioridade para novas oportunidades e adensamento das cadeias e inclusão social, com especial interesse sobre os recursos hídricos; e

4) Eixo Madeira-Amazonas e Arco Norte: com recursos para conservação e com prioridade para desenvolvimento inovador, biodiversidade e integração internacional.

\section{Delimitação geográfica dos Enid's} referente ao PPA 2000-2003

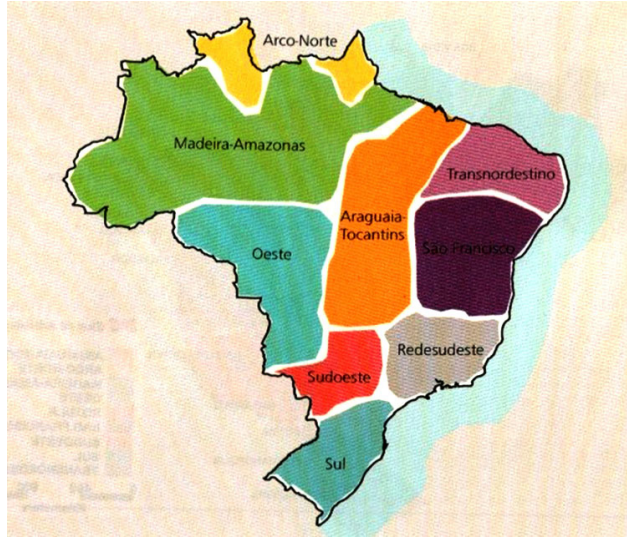

Elaboração: Consórcio Brasiliana (2000). Fonte: Galvão e Brandão, (2003, p. 223). 
A proposta dos eixos proporcionou uma nova regionalização para a provisão de investimentos com base na lógica produtivista e vinculada à infraestrutura regional. Sua justificativa operava-se pela perspectiva de desconcentração de projetos e investimentos e pela possibilidade de melhor distribuição dos impactos de desenvolvimento entre as regiões. Baseou-se em "projetos-âncoras" de infraestrutura, certamente a estratégia mais pragmática e eficiente no retorno dos investimentos. Contudo, não se consolidou no plano das ações sociais, mais dispersas pelo território e pouco privilegiadas no portfólio de projetos.

Essa proposta sofreu, ainda, uma revisão. Com a necessidade de atualizar o Portfólio de Oportunidades de Investimentos Públicos e/ou Privados, o BNDES abriu novo edital para revisão do portfólio e adequação do conceito dos eixos para integrar o PPA 2004-2007. 0 consórcio vencedor, Monitor, foi composto pelas empresas Monitor Group e Boucinhas \& Campos e unificado ao consórcio constituído pelas empresas Booz-Allen \& Hamilton e UMAH.

A proposta dividiu os eixos em cinco fases, valorizando o aspecto microeconômico através do reconhecimento dos clusters regionais, vinculados a estudos de competitividade (Manzoni Neto, 2013, pp. 113-114). Mudanças de gestão no poder executivo e, consequentemente, das políticas provocaram alterações nos programas públicos federais, e os eixos deixaram de ser elemento estruturador nos planos seguintes.

\section{Eixos de Integração \\ e Desenvolvimento (EID) da lirsa, a partir dos anos 2000}

No âmbito continental, a definição dos Eixos de Integração e Desenvolvimento está baseada na ideia de franjas multinacionais do território sul-americano onde se concentram espaços naturais, assentamentos humanos, zonas produtivas e fluxos comerciais. Esses eixos foram propostos pela iniciativa para a IIRSA (Integração de Infraestrutura Regional Sul-Americana) e, segundo seu argumento, representam uma referência territorial para o desenvolvimento sustentável da região, facilitando o acesso a zonas de alto potencial produtivo que se encontram atualmente isoladas ou subutilizadas, devido à deficiente provisão de infraestrutura econômica. São ordenados para facilitar o fluxo de bens, serviços, pessoas e informações dentro do território dos doze países sul-americanos (Argentina, Bolívia, Brasil, Chile, Colômbia, Equador, Guiana, Paraguai, Peru, Suriname, Uruguai e Venezuela) e desse com o restante do mundo. Atualmente, são ao todo dez os EID's, e foram propostos com a finalidade de promover a integração territorial sul-americana e potencializar sua competitividade diante de um contexto de reorganização regional de blocos comerciais. ${ }^{2}$ Os dez eixos são: 1) Andino, 2) Andino do Sul, 3) Capricórnio, 4) Hidrovia Paraguai-Paraná, 5) Amazonas, 6) Dos Escudos Guianos, 7) Sul, 8) Interoceânico Central, 9) Mercosur-Chile e 10) Peru-Brasil-Bolívia. 
Cada um desses eixos delimita uma área de influência que se consolida como uma região apta a receber recursos para propiciar desenvolvimento econômico sustentável. Sua origem está na influência brasileira sobre a criação da lirsa, ocasião em que foram apresentados o mesmo documento de Batista (na sua versão em inglês: Infrastructure for Sustainable Development and Integration of South America, 1996) e o documento "Eixos da América do Sul impulsionarão desenvolvimento" (de José Paulo Silveira, 2000 ). Mas, também, nos estudos apresentados pelo CAF (Vías para la Integración, 2000) e pelo BID (Un nuevo impulso a la integración de la infraestructura regional en América del Sur, 2000 ), na mesma ocasião. Como resultado, após a fundação da lirsa, foi apresentado um Plano de Ação (elaborado conjuntamente pelo BID, CAF e Fonplata, ${ }^{3}$ entre outros órgãos regionais) com destacada importância aos eixos na estruturação territorial.

A influência do documento de Batista é fundamental para entender o panorama sobre o qual se montam os fundamentos propagados pela lirsa através de seu Plano de Ação e do seu expoente territorial, o EID, pois o documento de Batista propôs a predominância do aspecto geoeconômico, em substituição ao geopolítico, no planejamento do desenvolvimento, a fim de obter benefícios econômicos pela integração sul-americana.

Nesse aspecto, é importante compreender a estrutura da lirsa. Criada em 2000 pela primeira reunião de presidentes sul-americanos realizada no Brasil, a lirsa teve o objetivo de iniciar um processo de integração e cooperação de múltiplos eixos que integrassem os doze países e impulsionassem a modernização da infraestrutura física a partir de uma concepção regional. Formou-se, então, a União de Nações Sul-americanas (Unasur) que culminou com o Tratado Constitutivo da Unasur, em 23 de maio de 2008 (em Brasília). Entre outras resoluções, esse Tratado estabeleceu vários conselhos setoriais no nível ministerial em diferentes âmbitos de trabalho, entre eles o Conselho Sul-Americano de Infraestrutura e Planejamento (Cosiplan), criado em 28 de janeiro de 2009, cujos objetivos centravam-se na infraestrutura regional, na integração entre os países-membros, na compatibilização de normativas e no apoio aos projetos prioritários. A partir de 2011, a lirsa vinculou-se ao Cosiplan, compondo seu Comitê Coordenador (ao lado dos Grupos de Trabalho), com a finalidade de ser o foro técnico para apoio do planejamento da infraestrutura de conectividade regional. A Cosiplan aprovou recentemente seu Plano de Ação (2012-2022).

0 maior legado dessa organização institucional ao redor de um conceito de eixo foi uma "Carteira de Projetos" de infraestrutura nos setores de transporte, energia e comunicações que foi proposta a partir da Metodologia de Planejamento Territorial Indicativa. Essa Metodologia partiu da identificação dos EID's como organizadores do território sul-americano para propor um conjunto de projetos de infraestrutura econômica vinculados ao território e que proporcionassem melhores funcionalidades logísticas dos investimentos e do desenvolvimento sustentável nas suas áreas de influência. A primeira versão da Carteira de Projetos foi elaborada em 2004 e, a partir de então, passou por sucessivas atualizações. Inicialmente previa um portfólio de 335 projetos de infraestrutura organizados em 40 Grupos de 
Projetos estimados em US\$37,42 bilhões. Em 2015, a Carteira foi formada por 593 projetos em 48 Grupos com salto de investimento para

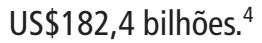

Embora com obras em andamento, as mudanças institucionais e o enfraquecimento da participação política brasileira pós-governos FHC minimizaram o protagonismo da lirsa e de suas ações efetivas de concretização dos eixos. As críticas, sobretudo aquelas geradas a partir dos impactos causados pela implantação de rodovias em áreas ambientalmente protegidas (como o caso do Eixo Peru-Brasil-Bolívia que passa pela Amazônia) e da falta de integração entre projeto econômico e projeto social, repercutiram negativamente, reposicionando o papel dos eixos infraestruturais na organização territorial da América do Sul.

\section{Projetos estratégicos de integração na América do Sul Agenda de implementação consensuada 2005-2010}

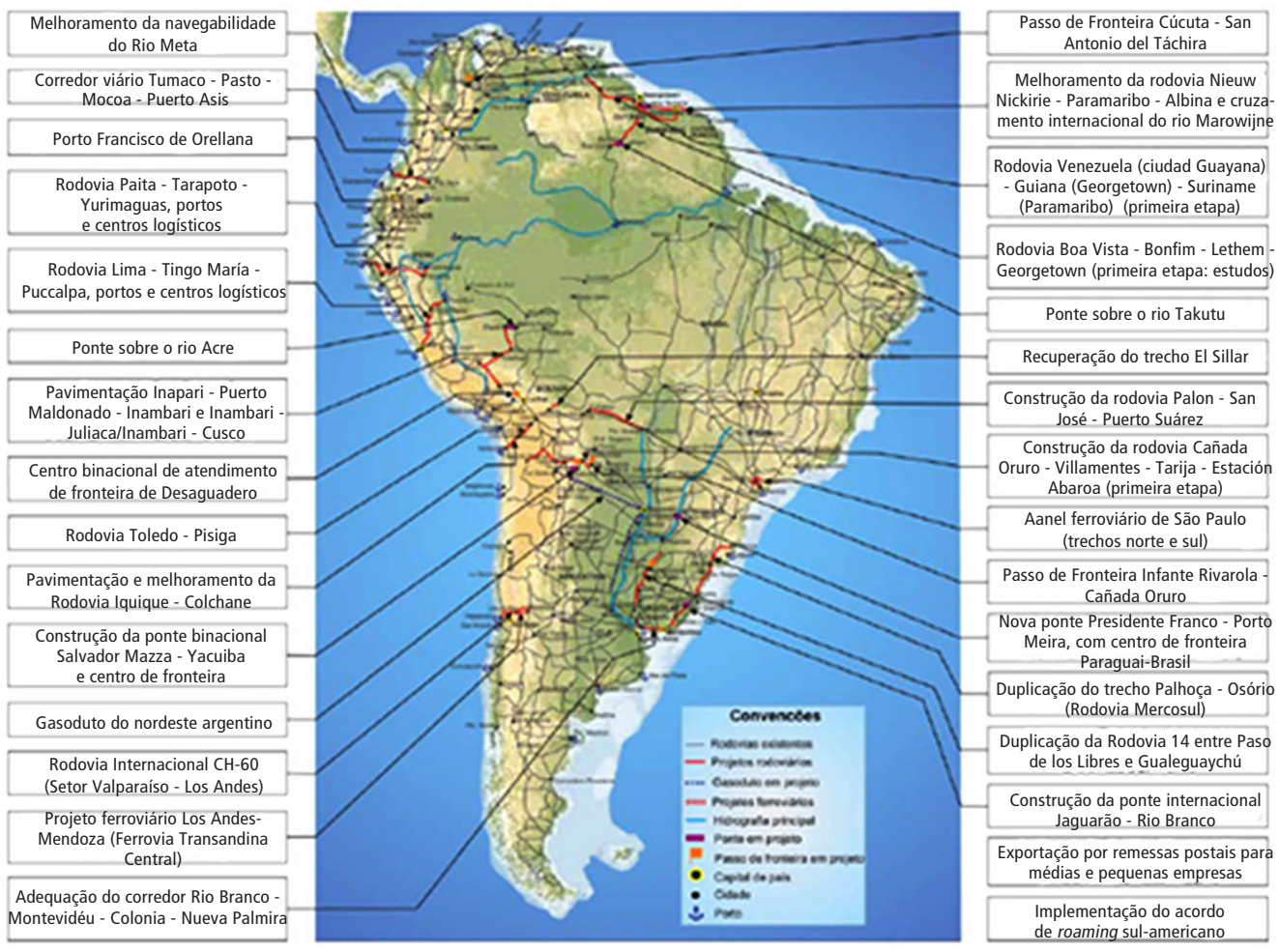

Fonte: lirsa (2004, p. 61). 


\section{EID's}

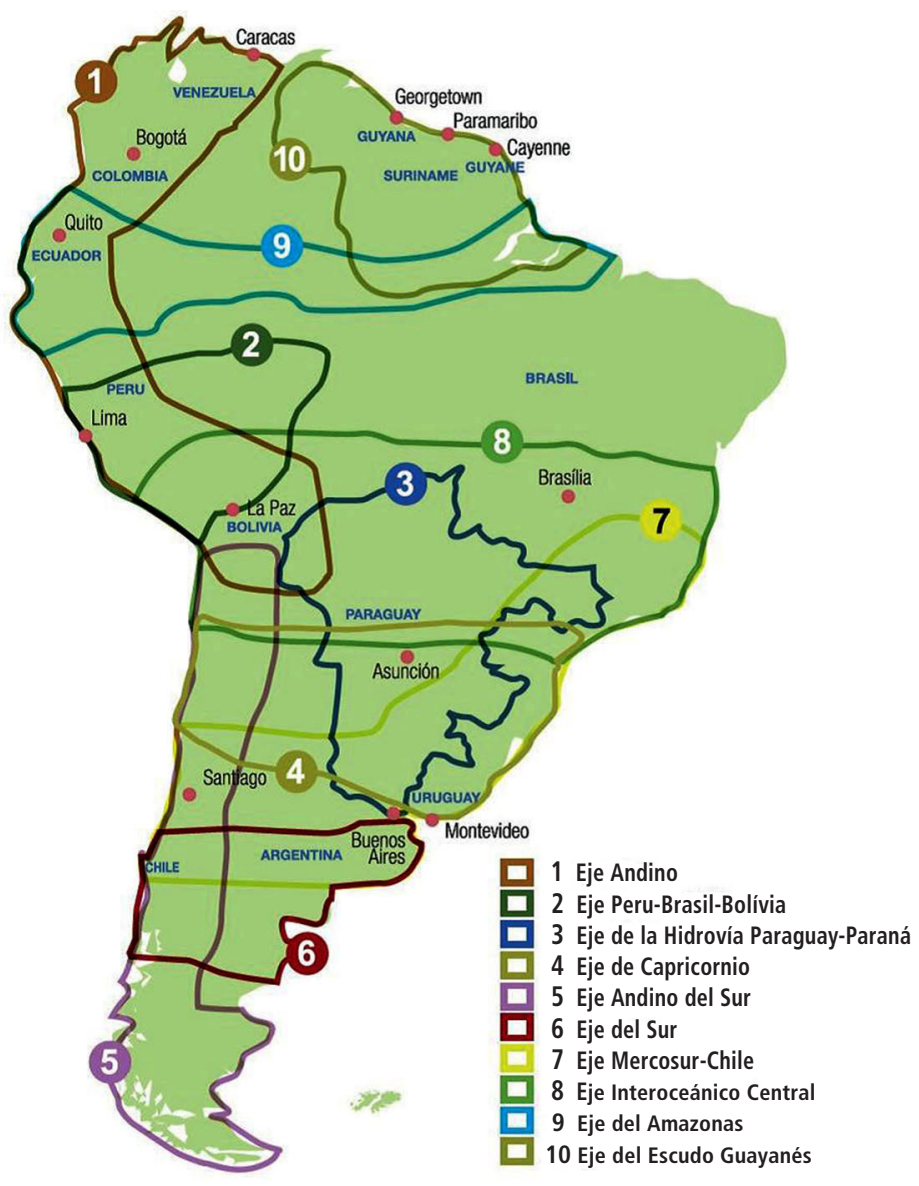

Elaboração: lirsa (2010).

Fonte: Ipea (2015, p. 32).

\section{Vetores Territoriais do Plano} de Ação da Macrometrópole Paulista, a partir dos anos 2010

No âmbito estadual paulista e segundo o Plano de Ação da Macrometrópole (PAM, 2014), Vetor Territorial é a denominação dada a um recorte geográfico de uma determinada área urbanizada da Macrometrópole Paulista (MMP) à qual é atribuída uma carteira de projetos com a finalidade de promover o desenvolvimento, o dinamismo e o restabelecimento das relações física e funcional nas diversas escalas do território (Governo do Estado de São Paulo, 2014b, p. 30). Desempenham influência intermetropolitana nas dinâmicas produtivas ou urbanas através de implantação/modernização de plataformas logísticas, rede ferroviária e complexo aeroportuário (Governo do Estado 
de São Paulo, 2014d, p. 30). Os Vetores Territoriais formam seis regiões delimitadas pela influência de alguns eixos rodoviários do estado de São Paulo e destinadas a intervenções de infraestrutura econômica:

1) Vetor de Desenvolvimento Região Metropolitana de São Paulo: abrange o território da Região Metropolitana de São Paulo com previsão de implantação de transporte de passageiros sobre trilhos, corredores metropolitanos de ônibus; plataformas logísticas; sistemas viário/ rodoviário e ferroviário de cargas; sistemas aeroportuários; sistema hidroviário metropolitano; dinamismo econômico e gerência dos recursos hídricos;

2) Vetor de Desenvolvimento Vale do Paraíba: abrange a ligação São Paulo/São José dos Campos/Taubaté, com previsão de implantação de sistemas de transporte sobre trilhos; integração de sistemas multimodais; sistema viário; articulação e infraestrutura logística; sistema de ciência e tecnologia (C\&T); uso do solo; e turismo ecológico;

3) Vetor de Desenvolvimento Caminho do Mar. abrange as ligações entre São Paulo Capital e Santos entre os centros logísticos, as vias e os modos de transposição da Serra do Mar, para carga e passageiros, em direção aos acessos do Porto, com previsão de sistemas de transporte sobre trilhos; sistema viário; articulação hidroviária; articulação e infraestrutura logística; e agilização burocrática;

4) Vetor de Desenvolvimento Bandeirantes: abrange a ligação de São Paulo/Jundiaí/Campinas/Rio Claro/Piracicaba, com previsão de ações nos sistemas de transporte sobre trilhos, no sistema viário, na integração de sistemas multimodais e na articulação e infraestrutura logística; e no uso do solo;
5) Vetor de Desenvolvimento Sorocaba: abrange a região a oeste da Macrometrópole Paulista (MMP), no eixo das Rodovias Castelo Branco e Raposo Tavares, com previsão de implantação de sistemas de transporte sobre trilhos; sistema viário; integração de sistemas multimodais; articulação e infraestrutura logística; e no uso do solo;

6) Vetor de Desenvolvimento Perimetral da Macrometrópole: abrange faixa territorial formada a partir do porto de São Sebastião em direção a São José dos Campos/Jacareí/Campinas/Sorocaba, com previsão de articulação de sistemas multimodais, portuário, plataformas logísticas; sistemas aeroportuários; eixos rodoviários e ferroviários de passageiros e cargas.

A rigor, os vetores territoriais estão orientados pelos principais eixos rodoviários do estado de São Paulo e abordam seus principais polos urbanos. Sua origem, portanto, está no reconhecimento da estrutura do território paulista constituída por polos e eixos e no predomínio dos trechos rodoviários como orientadores territoriais das ações futuras de planejamento por concentrarem adequada infraestrutura e um potencial parque linear industrial e logístico em toda sua orla. Eles (os vetores territoriais) constituem, ao lado dos vetores sistêmicos (cinco grupos sistêmicos de serviços e recursos naturais: recursos hídricos e saneamento; desenvolvimento ambiental; sistema de energia; inovação tecnológica, qualificação da mão de obra e gestão fiscal; desenvolvimento habitacional), a delimitação física e temática, respectivamente, do conjunto de projetos, programas e planos propostos pelo PAM (Governo do Estado de São Paulo, 2014b, pp. 37-38 ). E, embora algumas parcas ações de uso do solo e gestão administrativa sejam mencionadas no 
decorrer do PAM, não há maior aprofundamento dessas ações, levando à compreensão do predomínio da infraestrutura (sobretudo a econômica) como prioridade de intervenção.

Para entender a origem e os efeitos dos vetores territoriais, é preciso compreender a Macrometrópole Paulista e o seu Plano de Ação. A MMP é formada por 172 municípios delimitados por um raio aproximado de 200 quilômetros da capital, São Paulo. Reúne as Regiões Metropolitanas de São Paulo, de Campinas, da Baixada Santista, do Vale do Paraíba e Litoral Norte e parte da Região de Sorocaba, as aglomerações urbanas de Jundiaí e Piracicaba e a microrregião Bragantina. Concentrava, em $2010,73,3 \%$ do total da população paulista, $82,7 \%$ do Produto Interno Bruto (PIB) do estado de São Paulo e $27,7 \%$ do PIB brasileiro e $50 \%$ da área urbanizada do estado (Governo do Estado de São Paulo, 2014a, p. 1). Para orientar o desenvolvimento da Macrometrópole, o governo do estado propôs o PAM como um conjunto de ações com o objetivo de direcionar as principais decisões administrativas entre os anos de 2013 e 2040. As diretrizes gerais do PAM são espacializar o planejamento, criar um processo contínuo e integrar os diferentes setores administrativos. Valorizar as funções estruturadoras da Macrometrópole (mobilidade e logística, saneamento ambiental e habitação) integrando setorial e institucionalmente os projetos e as ações. Enfim, definir os parâmetros da Política de Desenvolvimento da Macrometrópole Paulista pela definição de uma carteira de projetos e investimentos.
Dessa forma, o PAM define três eixos estratégicos, ou ideias-chave, que orientam as ações: Eixo 1) Conectividade territorial e competitividade econômica, dando importância às condições logísticas e de infraestrutura produtiva e de circulação econômica, além da criação de ambiente de negócios através da concentração de empresas, centros de negócios e instituições financeiras. Eixo 2) Coesão territorial e urbanização inclusiva, abordando o desafio de desenvolver o território de forma inclusiva, sustentável e equilibrada. Eixo 3) Governança metropolitana, tratando da organização político-institucional no que diz respeito, principalmente à accountability da carteira de projetos. 0 que se objetiva com esses conceitos é uma Macrometrópole "una", "diversa", "policêntrica", "compacta" e "viva" (Governo do Estado de São Paulo, 2014a, p. 11).

Dessa forma, os vetores territoriais conformam-se como o espaço prioritário sobre o qual se desenrolam essas propostas através de planos, programas, projetos e obras que, reunidos na carteira de projetos, somam um investimento aproximado de $\mathrm{R} \$ 415$ bilhões para serem aplicados entre 2013 e 2040. Do que se observa das prioridades da carteira de projetos, o Vetor de Desenvolvimento da Região Metropolitana de São Paulo concentra mais de $65 \%$ dos investimentos previstos nos vetores territoriais, e as obras infraestruturais, sobretudo as de logística e de circulação de pessoas (rodoviária e ferroviária), consomem a maior parte dos recursos totais da carteira de projetos. 
Macrometrópole Paulista e os vetores territoriais do PAM

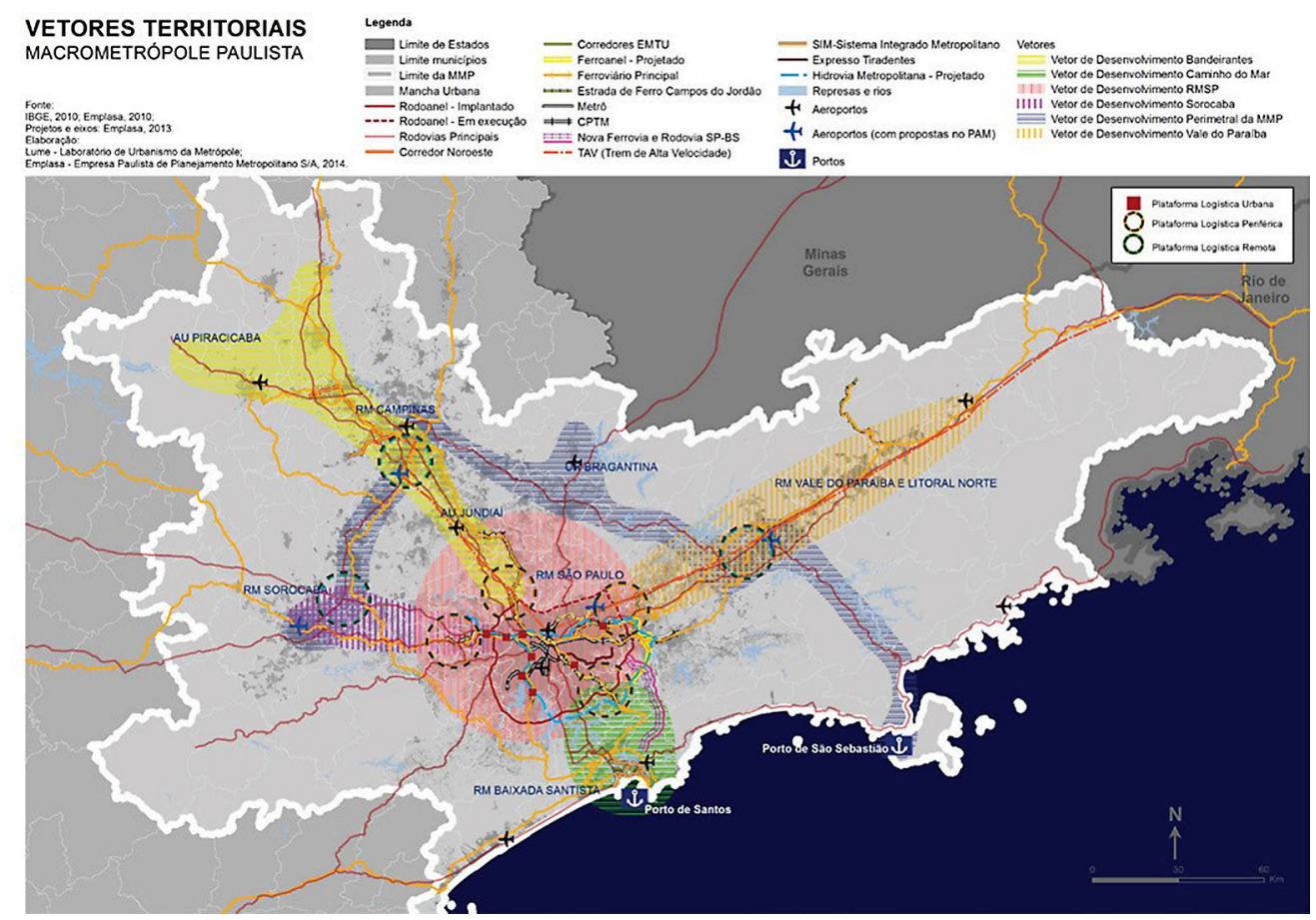

Fonte: Governo do Estado de São Paulo (2014c, p. 33).

\section{Filiações e conceitos: a resposta territorial à reestruturação produtiva}

A ideia de eixo como uma larga faixa sob influência de uma via com potencial de desenvolvimento que se constitui numa região objeto de provisão de infraestrutura e de ações planejadoras, presente nas três formulações acima, não é novidade no debate regional. Foi abordada nos estudos de Perroux quando tratou dos polos de crescimento (dos anos 1950) (Perroux, 1966a, v. III, pp. 35-38) e foi utilizada em estudos de novas rodovias (a partir dos anos 1960). Talvez um caso emblemático dessa prática tenha sido o estudo para a Rodovia Castello Branco, no estado de São Paulo. Proposta em 1963, sua concepção partiu da necessidade de interligar áreas em desenvolvimento pouco atendidas pelo modal rodoviário que apontavam para uma nova fronteira econômica, ou seja, a articulação entre o estado de São Paulo com os estados do Mato Grosso do Sul e do Paraná e o Paraguai. Seus estudos denominaram-na Eixo de Desenvolvimento Econômico e definiram regiões sob sua influência que teriam seu desenvolvimento potencializado pela 
construção da nova rodovia. Prática que se tornou recorrente e aprimorada ao longo das décadas posteriores com estudos de novas rodovias e a delimitação de regiões para o desenvolvimento sob sua influência (Tavares, 2015).

0 que se avançou dos modelos de eixos dos anos 1950/1960 para os eixos propostos nas últimas duas décadas? Permaneceu a ideia de uma regionalização a partir de um fluxo, mas suas finalidades foram adequadas ao contexto da reestruturação produtiva qualificando o território com fins à integração, à conectividade e à competitividade no mercado nacional e internacional. A concepção do BID (2000) é paradigmática desse novo modelo de organização territorial:

La interacción espacial da lugar a flujos, que en general no circulan en forma libre en el espacio, sino que lo hacen a través de las redes de infraestructura. Por ello, los fujos que serán objeto de análisis son los de bienes, de personas, de información, de energia eléctrica, de gas y de petróleo. Estos flujos, al circular por las redes de infraestructura, suelen consolidar sus movimientos en algunos tramos, conformando corredores.
En una escala regional, en la medida en que estos corredores favorecen el desarrollo económico y social de las áreas que recorren, pueden convertirse en verdaderos ejes de integración y desarrollo, constituyendo una herramienta de primer orden para vertebrar la organización del território. (p. 14)

Institucionaliza-se uma forma de regionalização a partir do tronco de infraestrutura econômica com o objetivo de constituir regiões para as ações planejadoras. Em resumo, o eixo é uma faixa de serviços que, integrada territorialmente e incorporada pelo planejamento, define uma região de influência a partir da qual serão destinadas provisões de infraestrutura (econômica, social, ambiental). Nasce dos fluxos da infraestrutura econômica, articula-se pelas redes existentes, forma troncos principais a partir de seus nós e capilaridades, constituindo uma região de provisão de recursos. Sua morfologia deve-se à reestruturação produtiva, cuja hierarquia não segue mais a hegemonia de um único centro macrocefálico, mas se baseia na conexão de vários hubs como propulsores das relações produtivas e comerciais.

Fluxos, redes, corredores e eixos

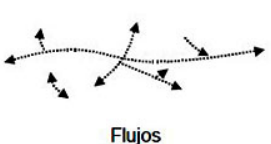

Flujos

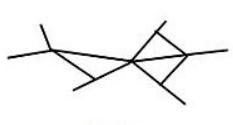

Redes

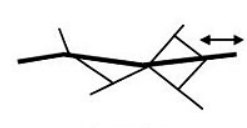

Corredores

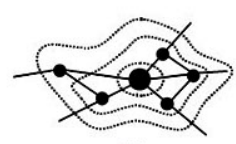

Ejes

Fonte: BID (ibid., p. 14). 
Sua constituição como ação planejadora está orientada por um novo contexto político e econômico que se inicia na redemocratização brasileira a partir das primeiras eleições diretas, em 1989. Os princípios econômicos adotados a partir de então baseiam-se na definição de um cenário de abertura econômica com vistas a um modelo de Estado mais enxuto ante a maior participação do capital privado nos serviços públicos. No PPA de 1991-1995, elaborado no governo de Fernando Collor de Melo (lei n. 8.173 de 30 de janeiro de 1991), fica clara a repercussão da ideia de reestruturação política e econômica expressa no seu art. $5^{\circ}, \S 1^{\circ}, 2^{\circ} \mathrm{e}$ $3^{0}{ }^{5}$ E do projeto político e econômico neoliberal de minimizar a participação do Estado nos serviços públicos, atribuindo-lhe funções reguladoras, enquanto, à iniciativa privada, caberiam as novas atribuições dos serviços públicos. Não foi a única ação nesse sentido, mas foi um importante prenúncio (na forma de plano) das políticas neoliberais que se consolidariam nas gestões presidenciais seguintes.

No primeiro governo Fernando Henrique Cardoso foi instituído o PPA para o quadriênio 1996-1999 através da lei 9.276, de 9 de maio de 1996, que trouxe, no seu anexo, as diretrizes, os objetivos e as metas do referido PPA. As estratégias contidas nesse anexo vislumbram o "aprofundamento do programa de desestatização" e a "reformulação e fortalecimento dos organismos de fomento regional" (Brasil, 1996b, sem página, item I.1 Das estratégias) com fins a reduzir os "desequilíbrios espaciais e sociais do país" (uma das três principais diretrizes do PPA) ${ }^{6}$ pela provisão de recursos para serviços públicos básicos de caráter social. As infraestruturas econômicas, por sua vez, ocuparam um espaço importante nessa proposta, sobretudo pela revisão das ações integradas entre Estado e iniciativa privada. Foram abordadas todas as áreas de transporte, de energia e de comunicações com vistas a modernização, ampliação e privatização de parte dessas infraestruturas e de previsão de aumento de atendimento nas áreas mais carentes do País (Brasil, 1996b, sem página, item II: Objetivos e metas da ação governamental, subitem: Infraestrutura econômica).

0 discurso de reorganização administrativa, investimentos públicos e privados nos setores econômicos de serviços públicos e a retórica pelo combate dos desequilíbrios regionais parecem ter criado uma estranha aproximação entre os preceitos da ciência regional predominantes a partir da década de 1950, de equilíbrio territorial do desenvolvimento, aos preceitos das políticas neoliberais, de privatização dos serviços públicos. Esse hibridismo fica muito evidente se analisarmos a proposta de Batista (1995) que está baseada no modelo de belt agrícola norte-americano (apud Faro; Pousa e Fernandez, 2005, pp. 12 e 157), segundo o qual uma grande região é atendida por ações, planos e projetos qualificadores com finalidade econômica. Seu conceito original, "sistêmico-holístico", partiu do aspecto geoeconômico para constituir espaços a partir de suas vocações produtivas articulando recursos naturais, energia e logística no âmbito nacional e sul-americano.

Os belts - ou eixos - foram concebidos como espaços econômicos e territoriais concretos, com certa harmonia em relação às vocações produtivas, cuja exploração deveria presidir a identificação dos principais projetos de eliminação dos gargalos de logística, para levar a produção aos 
mercados de forma competitiva - uma política de desenvolvimento industrial e, ao mesmo tempo, associada a projetos de infraestrutura, que permitiriam a alocação na produção. (Raphael de Almeida Magalhães apud Faro; Pousa e Fernandez, 2005, p. 12)

Eles opunham-se ao modelo de corredores de exportação, pois deveriam articular-se com o entorno e promover o contágio do desenvolvimento nas áreas lindeiras com potencial produtivo. Para o funcionamento, contudo, era necessário ajuste da infraestrutura, sobretudo a econômica, para articular matéria-prima, recurso humano e mercado consumidor.

Entender os eixos é respeitar a mais-valia das potencialidades tanto de uma microárea como de uma macroárea. É necessário integrar internamente regiões economicamente viáveis. Depois, essas áreas serão integradas à América do Sul. Esta, por sua vez, será integrada ao mundo [...]. (Depoimento de Eliezer Batista apud Faro; Pousa e Fernandez, 2005, p. 157)

Esse hibridismo em aproximar os preceitos desenvolvimentistas ao contexto neoliberal pode ser mais bem compreendido se visualizarmos o caminho percorrido por essa proposta. Os estudos de Batista foram encomendados pelo governo de Fernando Collor de Melo (19901992) e aprofundados no governo de Itamar Franco (1992-1995), por solicitação do então ministro das Relações Exteriores, Fernando Henrique Cardoso (e financiados pelo Business Council for Sustainable Development - Latin America). Fernando Henrique Cardoso, por sua vez, adotaria a ideia já no seu primeiro mandato como presidente (1996-2003), mas não seu conceito integral, e a aplicaria aos PPA's e aos seus programas políticos "Brasil em Ação" e "Avança Brasil". Ao ser incorporado pela proposta do Consórcio Brasiliana, o modelo de Enid's foi adaptado com base nas ideias dos polos de desenvolvimento (1950 e 1960) e de "região de planejamento" de Boudeville (Manzoni Neto, 2013, pp. 111-112), deflagrando esse hibridismo não só de conceitos, mas e sobretudo de posturas teórico-metodológicas de períodos distintos. Aliás, sintomático do diálogo com os argumentos do PPA 1996-1999, em que predominou o discurso do combate aos desequilíbrios espaciais e sociais bem ao gosto do debate regional que predominou no Brasil entre os anos 1950-1970. Dessa forma, os Enid's transformaram-se na plataforma territorial sobre a qual se dispunham projetos de investimentos do setor público e privado com fins a incidir na área de influência dos eixos. Investimentos com "objetivo último de fortalecer, com o máximo de participação privada, os Eixos de Integração e Desenvolvimento como vetores de maior competitividade econômica e menores desequilíbrios sociais e regionais". ${ }^{7}$

Esse modelo foi novamente alterado quando incorporado pelos EID's da lirsa que, mesmo sob forte influência do governo de FHC, redesenhou seu modelo de eixo a partir do debate da constituição de novos mercados econômicos unificados com proposta de "modernização da infraestrutura física da América do Sul em áreas de transporte (...)" (lirsa, 2011, p. 7). E manteve a ideia de grandes cinturões de desenvolvimento na escala continental e de maneira integrada a partir das infraestruturas econômicas.

Os ecos da década de 1950 também exerceram influência sobre os EID's da lirsa 
pela Cepal, contudo de maneira atualizada e baseando-se na sua resposta à reestruturação econômica mundial, sob a noção do "Regionalismo Aberto", pela defesa da cooperação regional e integração hemisférica a partir da sua visão produtiva com equidade e do reforço da concorrência (ibid., nota 2, pp. 21-22).

Nas perspectivas do regionalismo aberto e do novo regionalismo, a integração regional seria um processo de liberalização comercial intrarregional que trabalharia fundamentalmente como um alicerce e um estágio do processo de liberalização comercial internacional, iniciado na Rodada Uruguai do Acordo Geral de Tarifas e Comércio - General Agreement on Tariffs and Trade (GATT) - e retomado na Rodada de Doha lançada no âmbito da Organização Mundial do Comércio (OMC). (Padula, 2014, p. 296, nota 4)

Um dos principais objetivos era garantir, aos países latino-americanos integrados, coesão e força para enfrentar o comércio internacional e suas oscilações. A integração (comercial, principalmente, mas física, também) mostrou-se como importante estratégia diante da nova configuração mundial do comércio e da reestruturação produtiva. Condições que atribuíam, à infraestrutura, papel fundamental na organização do território por promover a integração dos fluxos pelo continente; exigir aproximações políticas que proporcionassem as compatibilizações entre essas infraestruturas; e otimizar economicamente a produção.

[...] Dessa forma, a Organização Mundial do Comércio como instância de regulação, os acordos de livre comércio e a união aduaneira seriam parte substantiva da agenda da integração. A abertura comercial e a integração seriam uma condição necessária para se promoverem 0 progresso técnico e o crescimento econômico com equidade. (Santos, 2014, p. 55)

A lirsa nasceu nesse contexto incentivada pelo: empenho neoliberal ao qual se inclinava boa parte dos governos que a apoiaram; pelo envolvimento desses governos nos tratados multilaterais, como Mercosul (Mercado Comum do Sul, criado em 1991) e Alca (Área Livre de Comércio para as Américas, criada em 1994); e pelos esforços desses governos em reposicionar o mercado e a iniciativa privada no papel antes ocupado pelo Estado. E sua função foi a de promover a integração infraestrutural para consolidar a conexão entre os países sul-americanos para lhes proporcionar maior competitividade no mercado (livre) internacional. 0 projeto neoliberal, portanto, transpassa as barreiras administrativas e político-econômicas e se consolida no território ante a reorganização mundial do comércio. E seu viés técnico não foge à regra da iniciativa privada, haja vista a importância das instituições bancárias na sua concretização (BID; CAF, atualmente Banco de Desenvolvimento da América Latina; Fonplata) e a predominância dos investimentos privados nos projetos e na própria construção dos Eixos:

A lirsa nasce sob uma concepção na qual ganha proeminência a necessidade de atração do setor privado para participar do equacionamento financeiro dos projetos, seguindo a lógica das privatizações e de participação mínima do Estado na economia, para atrair investimentos em infraestrutura para a região e, consequentemente, para os governos que buscavam uma alternativa para viabilizar novos investimentos [...]. (Padula, 2014, p. 312) 
No caso do PAM, embora ele não apresente as bases conceituais e seu histórico remeta-se mais à rotina do planejamento estadual, ele também foi elaborado e proposto em meio a uma gestão de viés neoliberal que se alinhava, há duas décadas, a esses preceitos sul-americanos e nacionais. Condição que justifica a utilização, constante, dos aspectos de conectividade e concorrência na organização territorial da macrometrópole e do predomínio de ações pautadas por grandes obras de infraestrutura econômica. A lista de seus principais desafios esclarece bem a importância: da competitividade econômica territorial para atração de mais investimentos; da conectividade da macrometrópole para proporcionar maior eficiência à integração das atividades produtivas. ${ }^{8}$ São parte da sua carteira de projetos obras de forte impacto produtivo, como centros logísticos, porto seco, retroporto, plataforma logística, plataforma remota, aeroporto, porto fluvial, porto marítimo e complexos aeroportuários.

0 que se segue, nas três esferas do planejamento (nas escalas continental, nacional e estadual), são ações alinhadas ao neoliberalismo e com explicitado vínculo à predominância da iniciativa privada como propulsora de investimentos. A bagagem neoliberal dessas propostas, decorrente dos governos predominantes nesse período, redundou num discurso de "desenvolvimento" inócuo, pois esteve menos vinculado a soluções sobre os passivos sociais e ambientais, e mais preocupado em criar ativos territoriais setoriais.

Definitivamente, a pauta da competitividade territorial apoiada na sua integração e conectividade com mercados mundiais consolidou um modelo de intervenção infraestrutural que redesenhou as fronteiras internacionais, nacionais e estaduais e tem consolidado o eixo como o principal mote físico-espacial de novas intervenções e investimentos.

\section{Convergências e paradoxos: os predomínios econômico, locacional e setorial}

Essas propostas de eixos têm em comum outros aspectos, além de serem concebidas sob um contexto político e econômico de reorganização regional do mercado internacional:

a) constituem uma boa parcela do planejamento regional pelo predomínio da infraestrutura econômica (comunicações, energia e, principalmente, logística ou transportes nos seus vários modais);

b) partem de um fluxo existente (material, como pessoas ou produtos; ou imaterial, como distribuição de energia ou sistema de comunicações) e a partir dele delimita uma região sob sua influência;

c) as regiões delimitadas pela influência dos eixos resultam em: manchas ora contínuas, ora descontínuas; podendo estar sobrepostas ou não; não se limitando às fronteiras municipais, estaduais ou nacionais, portanto rompendo a ideia clássica de regionalização como a prática do agrupamento de áreas confinadas e reunidas por algum tipo exclusivo de similaridade;

d) promovem a integração territorial reproduzindo no espaço as soluções para as necessidades econômicas de conectividade produtiva e aumento de competitividade;

e) morfologicamente, contrariam o modelo macrocefálico típico da cadeia produtiva 
fordista monocêntrica, ao compor múltiplas relações hierárquicas e corresponder aos novos padrões produtivos;

f) são formuladas a partir da nova matriz econômica neoliberal, com importante parcela de investimento privado;

g) estão inseridas em programas mais abrangentes (de âmbito político ou técnico), nos quais apresentamnotória relevância estrutural;

h) incorporam, no discurso, questões sociais e ambientais, embora o foco permaneça na produtividade;

i) retomam o debate regional pelo viés interescalar (nos âmbitos continental, nacional e estadual), excluindo, contudo, o debate no âmbito local, sobre o qual os reflexos negativos dessas implantações são mais impiedosos e no qual emergem com mais força os temas sociais e ambientais;

j) dividem um mesmo vocabulário (são comuns os termos: plano de ação [PAM] ou plano de ação estratégica [lirsa]; carta de projetos [lirsa] ou carteira de projetos [PAM]; portfólio de investimentos [Consórcio Brasiliana]) que, para além da similaridade de termos, explicita uma afinidade programática de intervenções de grande porte na qualificação do território para modernizá-lo como novo ambiente de investimentos do capital privado.

Algumas dessas características não foram poupadas pelas críticas recentes. Nos três casos (Enid's, EID's e Vetores Territoriais), essas críticas têm-se pautado pelas questões econômicas; pelos privilégios localistas das intervenções em áreas historicamente mais desenvolvidas e aptas ao (maior) desenvolvimento; e pelo caráter setorial das propostas. De forma geral, identificam o predomínio neoliberal que se instala no planejamento de regiões já qualificadas e inseridas no contexto produtivo e que se constitui como ações com concentração de investimentos nos setores de energia, comunicações e transporte. Embora as propostas dos eixos se justifiquem pelo espraiamento dos efeitos positivos dessas ações sobre as regiões delimitadas, as regiões com menor potencial produtivo e, em geral, as mais carentes ficam à margem dos investimentos. Condição que, em grande parte, explica a - praticamente - ausência de investimentos nos equipamentos sociais e nas medidas mitigadoras ambientais.

A primeira crítica mais contundente sobre os Enid's que, sem prejuízo da escala, pode ser estendida para os EID's (da lirsa) e para os Vetores Territoriais (do PAM), parte dos estudos de Galvão e Brandão (2003, pp. 187-205) que filiaram a proposta brasileira ao contexto político e econômico de princípio neoliberal e apontaram seu distanciamento da escola de planejamento que se consolidou no período desenvolvimentista.

[...] Curiosamente, ao invés de um momento de ruptura e mudança, aquele da formulação da proposta dos "eixos" [Enid's, complemento nosso] representou a continuidade em relação às opções neoliberais assumidas no início da década [de 1990, complemento nosso]. [...] As privatizações, concessões de serviços públicos, desmonte de controles estatais e outras medidas assemelhadas continuaram seu curso por toda a década, atestando a inexistência de solução de continuidade [...]. (Ibid., p. 188)

[...] Traços essenciais daquele período [desenvolvimentista, complemento nosso], sim, estavam sendo definitivamente abandonados. (Ibid., p. 189) 
Em que pese a influência dos polos de crescimento sobre o conceito de eixos, esses se distanciam daqueles sobretudo quanto ao foco e à maneira dos investimentos. Enquanto os polos buscavam o equilíbrio territorial pela dissipação do desenvolvimento pela indústria motriz e pela integração territorial de sua cadeia, os eixos preveem investimentos setorizados na infraestrutura produtivista. Ambos contam com investimentos privados (pela indústria, no caso dos polos; pelas parcerias entre capital público e privado, no caso dos eixos), contudo as políticas que incentivam os eixos, paradoxalmente, provocam uma concentração de ativos em regiões já privilegiadas por investimentos, contrariando os objetivos de equilíbrio regional. Essas diferenças aumentam quando analisadas as passagens que se dão do aspecto geopolítico para o geoeconômico; desenvolvimentista para o neoliberal; estatal para o privado; e, em última instância, do equilíbrio territorial para a competitividade-integração-conectividade territoriais. A entrada do capital privado na provisão dos serviços de caráter público reforça essa mudança. No PAM, esses papeis ficam bem definidos:

PPP:

Essas novas formas de relação público-privada estão no centro da estratégia de desenvolvimento da Macrometrópole preconizada no PAM. Assegurar o desenvolvimento dessa região pressupõe que grandes investimentos sejam realizados. E estes dependem de financiamento e da ação de atores privados que encarem 0 território da MMP como um local seguro para investimentos, com prazo garantido e regras estáveis. (Governo do Estado de São Paulo, 2014d, p. 158)
De acordo com a natureza dos investimentos dos Projetos da Carteira do PAM, cerca de $56 \%$ demandam a participação de recursos privados, seja em forma direta, seja por meio de PPPs e concessões. (lbid., p. 179)

Considerando que o equacionamento da política neoliberal depende dos investimentos privados e que estes dependem de retornos favoráveis, consolida-se um ciclo vicioso garantido pela decisão locacional. Com o abandono dos princípios desenvolvimentistas (diga-se de passagem, que estavam baseados, entre outros paradigmas, no da industrialização), também se abandonou o princípio de equilíbrio territorial do desenvolvimento (presente nos discursos de planejadores no início da segunda metade do século XX). Assim, o privilégio em atender áreas já potencialmente desenvolvidas (ou em curso de desenvolvimento) pelo aporte de recursos de infraestrutura econômica deixou de lado 0 atendimento às áreas mais carentes e a prioridade por equipamentos de natureza social. Pois, afinal, a primazia do investimento privado condiz com a certeza de lucros dos recursos aportados. Em sintonia com a questão econômica segundo a qual os eixos respondem aos preceitos neoliberais, entram em debate as escolhas locacionais a partir das quais predominam investimentos em áreas já qualificadas e aptas à maior produtividade. Nos EID's, por exemplo, a decisão locacional optou por baixo investimento no Eixo do Escudo das Guianas que, mesmo estratégico para a região, possuia "baixo grau de desenvolvimento" (Padula, 2014, p. 335). Já, nos vetores territoriais, a área mais privilegiada com investimentos $(65 \%$ do total destinado aos vetores territoriais) é 0 
Vetor de Desenvolvimento da RMSP (Governo do Estado de São Paulo, 2014d, p. 179), região tradicionalmente mais desenvolvida e com certeiras possibilidades de retornos.

Embora a organização territorial dada pela lógica da atividade produtiva como cerne do desenvolvimento não fosse uma inovação das estratégias dos eixos (pois a ideia de polos de crescimento de Perroux partia da indústria motriz como difusora de desenvolvimento), as escolhas locacionais para implantação desses eixos têm-se pautado pela potencialidade de concorrência dessas regiões. Ao propor uma regionalização estadual, nacional ou continental por eixos infraestruturais em "regiões ganhadoras" ou com potencial de desenvolvimento, fica clara a opção por áreas já equânimes em relação à produtividade. Ficam de fora, portanto, as áreas com conflitos e contradições sociais e ambientais que, em geral, necessitam de mais atendimento e, por isso mesmo, não representam certezas de investimentos.

E em relação ao tipo de aporte de investimento, nos três casos, predomina a setorização da infraestrutura em energia, comunicações e transportes com larga vantagem do modal rodoviário. Na concepção dos Enid's, por Batista, esse princípio já se destacava como estrutural (apud Faro; Pousa e Fernandez, 2005, p. 157). Nos EID's e nos Vetores Territoriais, eles ficam evidentes no percentual de recursos destinados a esses setores da infraestrutura em comparação com os demais investimentos. Nos EID's, a previsão de investimentos estimados pelo Cosiplan, para 2016, considerou boa parte destinada aos transportes:

Com respeito ao perfil setorial da carteira API, a tabela 11 evidencia que os investimentos previstos se limitam aos setores de transporte e energia, com forte concentração de projetos no setor de transporte, o qual corresponde a $94 \%$ do número de operações e $91 \%$ dos valores previstos de investimentos. No âmbito desse setor, mais de $50 \%$ dos investimentos se localizam no modal rodoviário [...] (Costa e Gonzalez, 2014, p. 37)

Nos vetores territoriais, os maiores investimentos são previstos também em logística, não apenas no aspecto quantitativo (que representa a maior soma de valores de investimentos), mas também no aspecto qualitativo, tendo em vista que são as ações com maior prioridade, além de serem classificadas como estruturantes (Governo do Estado de São Paulo, 2014d, p. 179).

Em resumo, essas ações baseadas territorialmente nos eixos e nas suas respectivas regiões de planejamento, orientadas por um portfólio de investimentos em grandes obras predominantemente infraestruturais, apontaram para uma estratégia de desenvolvimento vinculado estritamente ao produtivismo em áreas historicamente mais desenvolvidas.

\section{Conclusão}

No nosso estudo, identificamos como a proposta de eixos (Eixos Nacionais de Integração e Desenvolvimento; Eixos de Integração e Desenvolvimento; e Vetores Territoriais) tem por finalidade organizar o território a partir da constituição de regiões sob influência de importantes faixas de infraestrutura econômica e como as propostas derivadas desses modelos dialogam com premissas neoliberais de qualificação do território pela sua competitividade na 
escala global. Tendo em vista essas evidências, podemos afirmar o protagonismo do eixo como novo padrão formal/espacial de organização territorial definido por políticas e programas de âmbito territorial proporcionados por governos estadual, nacional e continental. Esse novo padrão, por sua vez, reforça a influência das atividades produtivas, pois se desenvolve por um diálogo entre as decisões locacionais e o capital privado, não apenas com investimentos na atividade industrial, mas também nos setores de serviços de interesse público. $E$, ao privilegiar mais as atividades produtivistas e as áreas mais competitivas, utiliza o argumento de "desenvolvimento" para justificar a modernização dos equipamentos infraestruturais.

Nesse contexto, a transposição de matriz predominante, que passa dos Polos de Crescimento para os Eixos de Infraestrutura, sugere um deslocamento conceitual do predomínio da escola francesa de planejamento para a escola americana. A ideia de difusão de desenvolvimento equilibrado, antes orientada pela geração de polos de crescimento, passa a ser orientada pela ideia de belts como regiões de planejamento de setores produtivos que, nos casos analisados, fundamentam-se pelos fluxos. Esse deslocamento é comprovado pela pioneira experiência de Eliezer Batista (1995) ao conceber seus eixos de infraestrutura a partir das experiências dos belts americanos e pela larga predominância de agências e bancos sul-americanos (sob influência das políticas norte-americanas) na conceituação e no financiamento desses eixos. Essa filiação, em diálogo com o contexto de reestruturação produtiva, parece articular instituições, capital e trabalho na construção de um paradigma que busca responder a um determinado contexto econômico mundial.

Por fim, podemos compreender que 0 modelo de eixos tem se enraizado de tal forma nas instituições de planejamento que, mesmo os antigos padrões de organização territorial, antes influenciados pela ideia de polos, estão sendo revistos à luz da lógica dos fluxos das dinâmicas produtivas. Haja vista a aprovação das duas novas regiões metropolitanas no estado de São Paulo: Região Metropolitana do Vale do Paraíba e Litoral Norte (2012) e Região Metropolitana de Sorocaba (2014). Em ambos os casos, o que parece ter predominado como fator decisivo para a definição dessas regiões metropolitanas não foi a constituição de uma metrópole polarizada a partir de suas principais cidades (São José dos Campos; Sorocaba) que por si são dependentes de polos maiores e geograficamente próximos (São Paulo e Campinas). Mas, foram definidas a partir das relações de fluxos instituídos pelos seus principais eixos rodoviários (Dutra, Ayrton Senna/Carvalho Pinto e Raposo Tavares/ Castelo Branco) que as interligam a esses polos maiores e, consequentemente, aos portos de Santos e São Sebastião, condizentes à urbanização dispersa (Reis Filho, 2006) em franco desenvolvimento. Na urbanização dispersa, boa parte das atividades cotidianas regionaliza-se ao longo das rodovias, ampliando a dependência da mobilidade, a valorização de espaços metropolitanos e intermetropolitanos, 0 espraiamento residencial e de serviços, a diminuição de densidade das áreas urbanizadas, o esgarçamento do tecido urbano e a constituição de uma "nebulosa" ou de uma constelação de áreas urbanizadas interdependentes 
e pouco compactas. Notáveis influências dos eixos como fator decisivo de mudança de um padrão de organização territorial.

A constatação desse paradigma parece provocar um novo desafio que vai além da compreensão do papel do eixo no planejamento regional. Trata-se da ausência da escala local nesse debate. Embora o planejamento por eixos ocorra no âmbito interescalar, ele não aborda a escala local. Menciona-a em algumas ocasiões, mas as ações prioritariamente não são a ela direcionadas. As condições de urbanização que se identificam nas principais cidades brasileiras, com maior evidência no estado de São Paulo e nas capitais estaduais, apresentam um grau de metropolização irreversível, sendo inevitável a inserção da escala local no debate regional. Sobretudo porque essas ações de âmbito regional interferem nas cidades a partir dos impactos sociais e ambientais que recaem sobre os espaços urbanos e seus usuários. Haja vista os conhecidos efeitos das decisões regionais exclusivamente setoriais sobre o ambiente urbano, nas décadas de 1960 e 1970, que legaram um modelo metropolitano fragmentado e com altos índices de problemas sociais e ambientais (Tavares, 2015, pp. 174-178).

Seria desejável que o debate regional extrapolasse 0 viés setorial produtivista materializado pelas faixas infraestruturais que constroem espaços exclusivamente econômicos e se voltasse para os espaços de concentração de pessoas, a rigor as redes urbanas. No planejamento regional, a rede urbana tem relevante destaque por ser um espaço prioritário de relações interescalares e por reunir a dimensão regional e o aspecto local numa tentativa de diálogo entre os espaços econômicos e as demandas sociais, pois é a relação urbano-regional que se tem mostrado essencial para a construção de novos paradigmas do planejamento regional. Tentando sintetizar esse desafio e tendo em vista a consolidação dos eixos como nova prática do planejamento, propomos o seguinte questionamento: quais deverão ser os novos paradigmas da organização territorial que, com foco na relação urbano-regional, podem alavancar o desenvolvimento da rede urbana brasileira?

\section{Jeferson Cristiano Tavares}

Centro Universitário Faculdades Integradas Alcântara Machado-Faculdades de Artes Alcântara Machado, Planejamento Urbano e Regional. São Paulo, SP/Brasil.

jctavares@gmail.com 


\section{Notas}

$(*)$ Este texto foi, em boa parte, motivado pelos debates sobre planejamento regional com Laisa Eleonora Stroher e Cintia de Souza Alves, a quem devo agradecimentos.

(1) O PPA (Plano Plurianual), a LDO (Lei de Diretrizes Orçamentárias) e a LOA (Lei Orçamentária Anual) são instrumentos de planejamento previstos na Constituição de 1988, no seu artigo 165 , cuja finalidade é garantir, à gestão pública administrativa a rotina de planejamento e o controle do investimento dos recursos públicos. Atualmente, os três entes federados (níveis federal, estadual e municipal) têm aplicado esses instrumentos.

(2) Disponível em: <http://iirsa.org/Page/Detail?menultemld=60>. Acesso em: 16 abr 2016.

(3) BID: Banco Interamericano de Desenvolvimento; CAF: Corporação Andina de Fomento, atualmente Banco de Desenvolvimento da América Latina; e Fonplata: Fundo Financeiro para o Desenvolvimento da Bacia do Prata.

(4) Disponível em: <http://iirsa.org/Page/Detail?menultemld=126>. Acesso em: 16 abr 2016.

(5) Art. $5^{\circ}$ : O Plano Plurianual de que trata esta lei, ao longo de sua vigência, somente poderá ser revisado, ou modificado, através de lei específica, sendo que o projeto de lei relativo à primeira revisão deverá ser encaminhado ao Congresso Nacional por ocasião da abertura da Sessão Legislativa de 1992(Vide lei no 8.446, de 1992).

$\S 1^{\circ}$ : Revisões do Plano Plurianual 1991/1995, nas condições e limites de que trata o caput deste artigo, deverão observar o seu ajustamento às circunstâncias emergentes no contexto social, econômico e financeiro, bem como a continuidade do processo de reestruturação do gasto público federal.

$\S 2^{\circ}$ : A reestruturação do gasto público federal terá como objetivos básicos:

a) assegurar o equilíbrio nas contas públicas;

b) aumentar os níveis de investimento público federal, em particular os voltados para a área social e para infra-estrutura econômica;

c) ajustar a execução das políticas públicas federais a uma nova conformação do Estado, que privilegie as iniciativas e a capacidade gerencial do setor privado e, ao mesmo tempo, fortaleça as inerentes ao Poder Público;

d) rever o papel regulador do Estado, com vistas à consolidação de uma economia de mercado moderna, competitiva e sujeita a controles sociais;

e) conferir racionalidade e austeridade ao gasto público federal;

f) elevar o nível de eficiência do gasto público, mediante melhor discriminação e maior articulação dos dispêndios efetivados pela União, pelos Estados, pelo Distrito Federal e pelos Municípios.

$\S 3^{\circ}$ : Para consecução dos objetivos referidos no parágrafo anterior, o Poder Executivo adotará as seguintes linhas de ação:

a) redução da participação relativa dos gastos com pessoal nas despesas públicas federais;

b) modernização e racionalização da Administração Pública Federal;

c) privatização de participações societárias, bens ou instalações de sociedades controladas, direta ou indiretamente, pela União, de conformidade com o Programa Nacional de Desestatização, criado pela lei $n^{\circ} 8.031$, de 12 de abril de 1990;

d) alienação de imóveis e de outros bens e direitos integrados do ativo permanente de órgãos e entidades da Administração Pública Federal direta, autárquica ou fundacional;

e) transferência de encargos públicos para os Estados, Distrito Federal e Municípios;

f) (Vetado)

(Lei no. 8.173, Art. 5ㅇ, § 1으, 2으 e 3ㅇ) 
(6) As três diretrizes eram: "Construção de um Estado Moderno e Eficiente; a Redução dos Desequilíbrios Espaciais e Sociais do País; e a Modernização Produtiva da Economia Brasileira" (Brasil, 1996b, sem página, item I. Diretrizes da Ação Governamental).

(7) Disponível em: <http://www.fazenda.gov.br/noticias/1998/r980901anx3\#wrapper, parágrafo 75>. Acessado em: 9 abr. 2016.

(8) "Principais desafios

- Aprofundar a competitividade econômica e a integração funcional entre os territórios da MMP.

- Atrair investimentos e/ou negócios, nos setores industrial e de serviços de média e alta intensidades tecnológicas. E investir na qualificação da mão de obra e na ampliação da oferta de educação tecnológica e técnica.

- Equacionar problemas de conectividade territorial por meio de complementação e integração dos principais sistemas de infraestrutura de suporte às atividades produtivas e de atendimento básico à população.

- Modificar a matriz dos deslocamentos de pessoas e mercadorias, por meio da ampliação da intermodalidade e da expansão das infraestruturas, além da integração entre rodovias, ferrovias, hidrovias, portos e aeroportos.

- Qualificar a MMP como o mais importante hub de transporte e comunicação do País.

- Tratar o território da MMP como "plataforma" de políticas públicas, projetos e ações articuladas, capazes de oferecer resposta adequada à complexidade dos problemas existentes, bem como à integração territorial e funcional entre suas unidades regionais.

- Implementar projetos articulados no âmbito do princípio da coesão territorial e urbanização inclusiva.

- Pactuar com os demais níveis de governo, os setores público e privado e com a sociedade a definição e implantação da carteira de projetos da Macrometrópole Paulista."

(Governo do Estado de São Paulo, 2014d, p. 11)

\section{Referências}

ABLAS, L. (2003). “O 'estudo dos eixos' como instrumento de planejamento regional”. In: GONÇALVES, M. F.; BRANDÃO, C. A. e GALVÃO, A. C. F. (orgs.). Regiões e cidades, cidades nas regiões: o desafio urbano-regional. São Paulo, Editora Unesp, Anpur.

BATISTA DA SILVA, E. (1997). Infraestrutura para o desenvolvimento social e integração na América do Sul. Rio de Janeiro, Expressão e Cultura.

BID. DEPARTAMENTO DE INTEGRACIÓN Y PROGRAMAS REGIONALES. DEPARTAMENTO REGIONAL DE OPERACIONES 1. DEPARTAMENTO REGIONAL DE OPERACIONES 3 (2000). Un nuevo impulso a la integración de la infraestructura regional en América del Sur. BID.

BRASIL (1996a). Brasil em Ação.

(1996b). Anexo (da lei n. 9.276 de 9 de maio de 1996 - PPA de 1996-1999).

(2001). Anexo I - Diretrizes estratégicas e macroobjetivos (do decreto n. 4.042 de 13 de dezembro de 2001 - PPA 2000-2003). 
BRENNER, N. (2010). A globalização como reterritorialização: o reescalonamento da governança urbana na União Europeia. Cadernos Metrópole, v. 12, n. 24, pp. 535-564. São Paulo, Educ.

COSTA, C. E. L. e GONZALEZ, M. J. F (2014). Infraestrutura e integração regional: a experiência da lirsa na América do Sul. Boletim de Economia e Política Internacional-BEPI, n. 18, pp. 23-40. Sem local. (Em nota os autores esclarecem: versão reduzida do Texto para Discussão do Ipea, intitulado "Infraestrutura física e integração regional na América do Sul: uma avaliação da Iniciativa para a Integração da Infraestrutura Regional da América do Sul” - lirsa).

FARO, L. C.; POUSA, C. e FERNANDEZ, C. (2005). Conversas com Eliezer Batista. S.I., Insight Engenharia de Comunicação.

GALVÃO, A. C. F. e BRANDÃO, C. A. (2003). "Fundamentos, motivações e limitações da proposta governamental dos 'Eixos Nacionais de Integração e Desenvolvimento'”. In: GONÇALVES, M. F.; BRANDÃO, C. A. e GALVÃO, A. C. F. (orgs). Regiões e cidades, cidades nas regiões: o desafio urbano-regional. São Paulo, Editora Unesp, Anpur.

GOVERNO DO ESTADO DE SÃO PAULO. SECRETARIA DA CASA CIVIL. EMPLASA (2014a). Plano de Ação da Macrometrópole Paulista. 2013-2040: política de desenvolvimento da macrometrópole. 1á edição. Volume 1. São Paulo, Emplasa.

(2014b). Plano de Ação da Macrometrópole Paulista. 2013-2040: uma visão da macrometrópole. 1’ edição. Volume 2. São Paulo, Emplasa.

(2014c). Plano de Ação da Macrometrópole Paulista. 2013-2040: cenários e desafios da macrometrópole. 1a edição. Volume 3. São Paulo, Emplasa.

(2014d). Plano de Ação da Macrometrópole Paulista. 2013-2040: carteira de projetos do PAM. 1a edição. Volume 4. São Paulo, Emplasa.

IIRSA (2004). Agenda de implementação consensuada 2005-2010. Relatório de Avaliação-julho de 2010. lirsa, BID, CAF, Fonplata.

IIRSA. COMITÉ DE COORDINACIÓN TÉCNICA (CCT). SECRETARIA DO CCT (2011). lirsa 10 anos depois: suas conquistas e desafios. 1a edição. Buenos Aires, BID-Intal.

IPEA (2015). Texto para discussão. Infraestrutura física e integração regional na América do Sul: uma avaliação da Iniciativa para a Integração da Infraestrutura Regional da América do Sul (lirsa). Rio de Janeiro, Ipea.

LOGAN, J. R. e MOLOTCH, H. L. (1987). Urban fortunes. The political economy of place. California, University of California, Press Berkeley and Los Angeles Press.

MANZONI NETO, A. (2013). Abordagem territorial no planejamento público federal no Brasil a partir dos anos 1990: uma análise da atuação de empresas de consultoria. GEOUSP - Espaço e Tempo. São Paulo, n. 34. Número Especial, pp. 106-118.

NASSER, B. (2000). Economia regional, desigualdade regional no Brasil e o estudo dos eixos nacionais de integração e desenvolvimento. Revista do BNDES. Rio de Janeiro, v. 7, n. 14, pp. 145-178.

PADULA, R. (2014). “Da lirsa ao Colisan da Unasul: integração de Infraestrutura na América do Sul nos Anos 2000 e suas perspectivas de mudança". In: DESIDERÁ NETO, W. A. (org.). O Brasil e novas dimensões da integração regional. Rio de Janeiro, Ipea. 
PERROUX, F. (1966a). “A unidade motriz na região e a região motriz. La empresa motora em uma região e a região Motora”. In: MECOR-SUDENE. ASSESSORIA TÉCNICA. DIVISÃO DE ASISTÊNCIA TÉCNICA AOS ESTADOS E MUNICÍPIOS. Seminário sobre pólos de desenvolvimento. Recife, Mercor-Sudene. Volume III, p. 12, 1966. (Separata da Revista Brasileira de Ciências Sociais. S. I., Universidade de Minas Gerais, v. 1, n.1, publicado originalmente em novembro, 1961.)

(1966b). "Notas sobre la noción de pólos de crecimiento. Consideraciones em torno a la noción de pólo de crecimiento". In: MECOR-SUDENE. ASSESSORIA TÉCNICA. DIVISÃO DE ASISTÊNCIA TÉCNICA AOS ESTADOS E MUNICÍPIOS. Seminário sobre pólos de desenvolvimento. Recife, Mercor-Sudene. (Separata de Cuadernos Venezelanos de Planificación, v. II, n. 3-4, pp. 3-8, publicado originalmente em 1966.)

REIS FILHO, N. G. (2006). Notas sobre urbanização dispersa e novas formas de tecido urbano. São Paulo, Via das Artes.

SANTOS, A. D. dos (2014). A integração da infraestrutura sul-americana e as dinâmicas do sistema-mundo capitalista: análise comparada das relações entre governos e bancos de desenvolvimento no Brasil, Peru e Bolívia. Tese de Doutorado. Brasília, Universidade de Brasília.

SCOTT, A. J. (1998). Regions and the world economy. The coming shape of global production, competition, and political order. Nova York, Oxford University Press.

TAVARES, J. C. (2015). Polos urbanos e eixos rodoviários no estado de São Paulo. Tese de Doutorado. São Carlos, Universidade de São Paulo.

UNASUR. COSIPLAN. FORO TÉCNICO IIRSA. COMITÉ DE COORDINACIÓN TÉCNICA (2015). Cartera de proyectos - 2015. Montevidéu, BID; Banco de Desarollo de América Latina; Fonplata.

Leis e decretos

Lei n. 8.173 de 30 de janeiro de 1991 - PPA de 1991-1995.

Lei n. 9.276 de 9 de maio de 1996 - PPA de 1996-1999.

Decreto n. 4.042 de 13 de dezembro de 2001 - PPA 2000-2003.

Texto recebido em 14/jan/2016

Texto aprovado em 31/mar/2016 
